\title{
Banking on change: information systems and technologies in UK high street banking, 1919-1969
}

\author{
BERNARDO BÁTIZ-LAZO and PETER WARDLEY \\ University of Leicester and University of the West of England
}

This article ${ }^{1}$ looks at the experience of management of technological innovation and mechanisation by British financial institutions. ${ }^{2}$ It highlights the indigenous assessment of technology, reflecting on local and American influences in two types of business organisations within the financial sector to demonstrate the nature of responses and the timing of the introduction of new methods and machinery. ${ }^{3}$ The adoption of Information Technology (IT) and computer applications in particular play a crucial role, though one that is intimately connected with a strategic expansion of corporate business, this growth being reflected in terms of size of business and also territorial expansion, as each of the institutions considered here constructed a national network of retail branch outlets. Discussion of established literature for the high

1 This article was originally circulated as 'Not another story of British backwardness? Information systems and technologies in UK high street banking, I919-1979'. Helpful comments from an anonymous referee, Trevor Boyns and critical participants at the conferences of the Society for the History of Technology (SHOT), Amsterdam 2004 and i ith Journées d'historie de la comptabilité, Bordeaux, 2005 are gratefully acknowledged.

${ }^{2}$ In the I980s the British high street banks, which provided retail financial services, were faced for the first time with direct competition (outside the mortgage markets) from building societies, which previously had functioned mainly as home-loan or thrift institutions. Building societies were founded as mutual organisations, though in the late I990s some were transformed into shareholder-owned companies. By the end of the twentieth century, the two institutions had converged to a rather similar organisational structure that provided very similar services.

3 Insurance companies, savings banks, some investment banks, Post Office banks and hire purchase organisations were among those intermediaries that, by the end of the twentieth century, had also converged into US and UK retail bank markets. The history of their automation is not fully documented though notable exceptions include Bernardo Bátiz-Lazo and J. Carles Maixé-Altes, 'The computerisation of British and Spanish savings banks, I960-2000' (paper presented at the Ioth Annual European Business History Association, Copenhagen, 2006); M. Campbell-Kelly, 'Large-scale data processing in the Prudential, I850-I930', Accounting, Business and Financial History, 2. 2 (I992), pp. I I7-39; Martin Campbell-Kelly, 'Data processing and technological change: the Post Office Savings Bank, I86I-I930', Technology \& Culture, 39. I (I998), pp. I-32; James W. Cortada, The Digital Hand, vol. 2 (New York, 2006); JoAnne Yates, 'The structuring of early computer use in life insurance', Journal of Design History, I2. I (1999), pp. 5-24. 
street banks is combined with archivally informed analysis of similar, but previously undocumented, developments on the part of building societies. By taking a longterm view of these developments in the twentieth century, and by comparing the experiences of two different sets of institutions, the article highlights the strategic factors that influenced the decisions taken by senior managers in their transformation of British retail financial services. ${ }^{4}$

\section{I}

Since their origins in the late seventeenth century, financial intermediaries working in British retail banking markets have undergone a sustained and continuous process of change that has altered their nature, size, structure and behaviour. In the last century they have also been the location of significant technological change - though as the locus of the diffusion of new technology rather than the development of novel machinery. And by their application of waves of new technology, financial intermediaries have adapted to change both what they do and how they do it. ${ }^{5}$

Inevitably, the nature of mechanisation and the type of technology introduced to achieve 'modernity' is a significant part of this article. However, our tale is not one of technological determinism. Rather, we believe that banks and building societies endeavoured to assess the costs and benefits associated with the adoption of new technologies and to act appropriately given their perceptions of the business environment. ${ }^{6}$ This altered significantly as the economic, social, political and cultural landscape was transformed by a number of factors, including the much expanded role of the state; the impact of war; changing perceptions of gender; and the development of a large managerial class and its increased professionalism. Although new technology underpins these developments, these additional themes also enlighten our story.

It is clear that, throughout the twentieth century, British financial institutions assessed practices abroad, though considerations of space preclude a detailed international comparison here. Similarly, as a central element of our story concerns the consolidation of national systems of corporate co-ordination and control, these processes occurred across the country rather than being uniquely located. Hence, the diffusion of the managerial procedures, techniques and associated technological innovations occurred within institutions that operated across geographical space. In short, our story highlights the longevity of technological change in retail finance.

${ }^{4}$ Peter Wardley, 'The commercial banking industry and its part in the emergence and consolidation of the corporate economy in Britain before I940', Journal of Industrial History, 3. 2 (2000), pp. 7I-97.

5 Ibid.

${ }^{6}$ Richard Coopey arrived at a different conclusion as he considered that banks 'in the US or in Britain considered direct costs a minor factor of purchasing systems .... [they] had little, if any, accurate idea of the cost-benefits of computing'. 'A passing technology: the automated teller machine', in P. Lyth and H. Trischler (eds.), Wiring Prometheus: Globalisation, History and Technology (Aarhus, 2004), p. I82. 
Given the prominence we give to directors and managers as agents of change, government is allotted here a relatively minor role. Although much can be made of the relative importance of the US and UK governments as sponsors of strategic computer hardware and associated applications, we emphasise the process of change that saw book-keeping and internal control brought about within clearing banks and building societies by office mechanisation. ${ }^{7}$ In particular, our story tells how technology in the form of office mechanisation and mechanical accounting (including computer applications) was introduced in the search for increasingly efficient book-keeping and internal control practices. Here there is an apparent contradiction. On the one hand, those financial intermediaries at the vanguard of technological change explored and adapted new applications to exploit existing operations as well as developing new capabilities. On the other hand, directors and senior managers of these intermediaries retained many of their internal practices largely unchanged as automation changed the execution of existing routine practices rather than first principles. Furthermore, developments in management control and cost accounting techniques were seldom advertised outside the industry. As a result, it is not surprising that external commentators sometimes accused clearing banks and, subsequently, building societies of managerial 'backwardness'.

The process of office mechanisation in clearing banks and building societies can be seen as a significant element of managerial practice that implemented a strategic intervention associated with management cost accounting. In a wider context, J. R. Edwards is among those who argue that some economic and business historians may have underestimated the development and impact of cost or management accountancy over the last two centuries. ${ }^{8}$ In similar fashion, R. Kee pointed to the scarcity of studies exploring mechanical and electromechanical devices in accounting history. ${ }^{9}$ While this research, for the most part, has concentrated on the manufacturing sector, here it is suggested that such a restricted view is unwarranted. ${ }^{10}$ Broadening this investigation to encompass institutions that provided services, and financial services in particular, shows clearly the recurrent appraisal of these techniques that informed implementation.

7 Respectively Jon Agar, The Government Machine: a Revolutionary History of the Computer (Cambridge, MA, 2003); S. W. Leslie, "The biggest "angel" of them all: the military and the making of Silicon Valley', in M. Kenney (ed.), Understanding Silicon Valley (Stanford, CA, 2000), pp. 48-67.

8 J. R. Edwards, The History of Accounting: Critical Perspectives on Business and Management, vol. I: Method and Theory and vol. 3: Cost and Management Accounting (London, 2000).

9 Robert Kee, 'Data processing technology and accounting: a historical perspective', The Accounting Historians Journal, 20. 2 (1993), pp. I87-2 I 5.

${ }^{10}$ For instance Thomas Tyson, 'The impact of advancements in manufacturing and information technology on management accounting systems', in T. A. Lee, A. Bishop and R. H. Parker (eds.), Accounting History from the Renaissance to the Present (New York and London, 1996). 
However, while clearing banks and building societies were willing to innovate in their methods of keeping records, there is ample evidence of critical assessments of the banking industry. First, these manifested themselves in a number of official documents: the Macmillan Report (1929); the Radcliffe Report (1959); the National Board for Prices and Incomes' Report on Bank Charges (I967); the Monopolies Commission ruling on the proposed merger of Lloyds Bank, Barclays Bank and Martin's Bank (I968); and the Cruickshank Report (2000). All criticised clearing banks, and perhaps by implication other financial institutions, including building societies, for a systemic failure to provide adequate venture capital to finance British industry. Furthermore, the more recent of these reports opined that these institutions had inadequate, if not poor, internal control practices. Second, similar views critical of the lack of sophistication in management accounting in banks and building societies have been expressed in various recent academic studies. ${ }^{11}$ Hence, with regard to managerial practices in British banks, it is not difficult to locate both implicit and explicit accusations of 'backwardness'. ${ }^{12}$

To some extent, clearing banks were responsible for the currency of these accusations as they failed to present their case to the authorities successfully. ${ }^{13}$ However, these indictments raise a number of questions regarding the expertise of those making the allegations, the criteria by which backwardness could be identified, the nature and quality of the supporting evidence, and the degree and extent of backwardness exhibited. These questions need to be answered in the context of the dominating view that guided banking regulation at the time of each enquiry, as well as contemporaneous corporate practices in banking current in the UK and elsewhere. Reflecting on this theme, this article contributes to the view which rejects the orthodox pessimistic position. ${ }^{14}$ That is, it abjures an assessment which affirms that the

11 Bernardo Bátiz-Lazo and Trevor Boyns, 'Automation and management accounting in British manufacturing and retail financial services, I945-68', paper presented at the Information Systems and Technology in Organisations and Society, Universitat Pompeu Fabra, Barcelona, 2003; C. Drury, 'Management accounting and information systems in UK building societies', The Service Industries Journal, I 8 (I998), pp. I25-43, C. Helliar, I. Cobb and J. Innes, 'A longitudinal case study of profitability reporting in a bank', British Accounting Review, 34 (2002), pp. 27-53; J. Innes and F. Mitchell, 'The application of activity-based costing in the United Kingdom's largest financial institutions', The Service Industry Journal, I7 (I997), pp. I90-203; P. Nightingale and R. Poll, 'Innovation and investment banking: the dynamics of control systems within the chandlerian firm', Industrial and Corporate Change, 9 (2000), pp. I I3-4I; K. Soin, W. Seal and J. Cullen, 'ABC and organizational change: an institutional perspective', Management Accounting Research, I3 (2002), pp. 249-7I.

12 Mark Billings and Forrest Capie, 'The development of management accounting in UK clearing banks, I920-70', Accounting, Business and Financial History, I4. 3 (2004); Alan E. Booth, 'British retail banks, I955-70: a case of "Americanisation"?', in M. Kipping and N. Tiratsoo (eds.), Americanisation in Twentieth Century Europe: Business, Culture, Politics (Lille, 200I); Richard Coopey, 'Management and the introduction of computing in British industry, 1945-70', Contemporary British History, I3. 3 (I999), pp. 59-7I; Coopey, 'A passing technology'; David Jeremy, A Business History of Britain, 1900-1990s (Oxford, I998).

13 Billings and Capie, 'Development of management accounting'.

14 Ibid. Booth, 'British retail banks, I955-70'; Wardley, 'The commercial banking industry'. 
major British clearing banks were managed ineffectively by conservative and technically naïve executive officers.

In summary, this discussion of the process of adoption of technology-using innovation in different types of financial intermediaries analyses the motivation and 'rationality' (albeit 'bounded rationality') of the senior managers of Britain's financial institutions. In particular, we discuss, to compare and contrast, the experience of enterprises in two initially distinct sectors within retail financial services: first, the retail operations of the clearing banks and, second, building societies. This allows us to highlight the common elements that characterise the process of technological diffusion that occurred in stages associated with different time periods, the adoption of early generations of IT, and within different institutions.

\section{III}

Clearly identifiable during the late nineteenth and early twentieth centuries in the history of British banking was the development of systems required to control and co-ordinate the business of a financial company which was conducted by a growing number of banking offices, retail branches or outlets, directed and supervised from a central office, the bank's headquarter offices. There were two fundamental aspects shared by each and every system of bank control developed during this period: first, the establishment of clearly specified and supervised routines which determined the organisation and nature of day-to-day business; and, second, the imposition of these established routines upon newly acquired, and previously independent, components of an amalgamated bank. In the latter case, the senior officers and directors of a bank would evaluate the strategic policy of the amalgamated bank to ensure control over lending and borrowing and establish the terms upon which business would be undertaken and, then, they would ensure their control over the implementation of this strategy by insisting on adherence to closely specified practices and protocols. Several features of this management system that ensured central command of resources can be identified. They include the provision and identification of premises where business would be conducted; the stipulation of the hours during which a retail branch would be open for business; 'draconian' inspection and internal audit policies and procedures; the creation of an internal labour market, which required the implementation of career structures; and, most important of all, the designation of power and authority within a retail branch network. ${ }^{15}$

An essential feature of this system, designed to ensure direction of a retail branch remote from the central offices, was the establishment of universally applied accounting procedures which ensured both the observation and the direction of retail branch activity. Usually, the direction and supervision of these managerial and accounting procedures were achieved by a strict insistence that the recording and transmission of information were undertaken according to a standardised format. For the senior officers of late

15 Wardley, 'The commercial banking industry'. 
nineteenth-century banks in Britain, rapid and convenient access to comprehensive data which was accurate, recent and recurrent was essential to conduct their management of the enterprise. One manifestation of this was the growing collection of ledgers, each laid out to a specific and specified design to meet a particular purpose, held while in use by the retail branch and, later, on completion, by the head offices of each bank. Another was the customised stationery designed to meet the requirements of communication internal and external to the bank. Additionally, the corresponding or equivalent records, which allowed the documentation of the progress of the whole enterprise, were constructed at the head office to allow both supervision and command of all the resources available. These systems, while obviously not perfect, were nevertheless highly successful in allowing both the observation and direction of ever growing financial institutions. ${ }^{16}$

The first two decades of the twentieth century saw great changes in the equipping of bank offices as new technology, embodied in telephones, typewriters, pneumatic communication tubes, photographic records, steel filing cabinets and electric lighting, became more common. As one expert opined, 'It may nowadays be said, without exaggeration, that machines and devices exist for handling the routine side of almost every kind of clerical work involved in banking, from opening the envelopes in the morning mail to sealing them up and stamping them for the evening mail.' ${ }^{17}$

One such innovation saw the adoption of the adding machine which could perform many essential but routine functions of basic arithmetic that were the norm for the overwhelming majority of operations undertaken in a bank. Within a year of its introduction in I90I, the Burroughs Adding Machine was being used in British banks for straight listing and casting and it was soon appreciated that this, and similar machines, provided an effective means to enter regular dividend payments, and then lists of entries and debits to customers' accounts. By the early I920s the adding machine was well established as a standard item of equipment at the Big Five's head offices and in larger branches.

Of much greater significance for the determination of business strategy and bank organisation was the introduction of accounting machines, which had the capacity to record and store operations. Ledger Posting Machines made possible the mechanisation of customer accounts, rendering them more legible, more accurate and more efficient than the pass books that had previously been the accepted technology. ${ }^{18}$ At the Midland Bank they were first introduced in the Overseas Branch, a discrete department within the bank which facilitated trial (and error), in 1926 to produce the balances on accounts. The results of this experiment were sufficiently promising for the Midland to plan a programme for the introduction of ledger posting machines throughout the bank. By the end of 1927 these machines had been further developed, by the addition of a proof strip or tally roll, which automatically recorded every item entered, so that the totals of debits

16 Ibid.

17 F. J. Ellis, 'New lamps for old: part III', The Spread Eagle, 6. Io (I93 I), pp. 5I 8-2 I.

18 Anonymous, 'Editorial notes', The Spread Eagle, 6. 8 (I93I), p. 40I; Wardley, 'The commercial banking industry'. 
and credits posted were recorded as were the new balances produced. An important feature of this facility was that it provided security in the form of an independent means of cross-checking the record of financial transactions. ${ }^{19}$

The Westminster Bank installed its first accounting machine at the Leicester branch in I929. This began a process of mechanisation of book-keeping at its retail branches by which machine-prepared statements replaced customers' handwritten passbooks. Although the first of the banks to complete its mechanisation project, it was only in 1956 that Westminster was able to celebrate the inclusion of every one of its I,200 branches; this event was marked at an informal ceremony when the final accounting machine (a National class 3000) was delivered to head office by executives of the National Cash Register Company (NCR). ${ }^{20}$

Electromechanical machine technology also facilitated the development of centralised registers which recorded the financial position, exposure and recent history of the bank and its component parts. Furthermore, it provided significant cost savings, through the substitution of relatively dear male labour by the relatively inexpensive combination of female labour and machines. ${ }^{21}$ While the significance and impact of machine banking is further developed below, it is important to note that its introduction was both earlier and more pervasive than is recognised in some of the recent literature that records this development: often the introduction of banking machinery is mentioned without reference to its broader significance for bank organisation; alternatively the introduction of banking machinery is dated erroneously from the end of the I930s, the late I940s or even the I950s. ${ }^{22}$

One example will suffice to demonstrate both the nature and maturity of this process. In I93 I J. Ellis, of Barclays Bank's Chief Foreign Branch contributed a three-part article to The Spread Eagle, the bank's staff magazine, which is both interesting and revealing for a number of reasons. First, it provides a brief but competent description of the technology that had already been adopted and was now being further diffused across Barclays branch network. Second, his contribution is well informed about technical and operational developments in banks overseas, especially in Germany and the United States of America, as well as at British banks, including Barclay's competitors on the English high street. ${ }^{23}$ Third, and obviously linking

19 H. L. Rouse, 'Mechanisation in the banks', paper presented at the Journal of the Institute of Bankers. Meetings of the British Bankers' Association and the Committee of London Clearing Banks, London, I930.

20 We appreciate Ian Ormerod alerting us to: Anonymous (P.W.F.), 'End of an era', NCR Post Monthly, circa May 1956. In an example of technological 'lock in', NCR manufactured the last of the Series 3000 shortly after.

21 Peter Wardley, 'Women, mechanization and cost-savings in twentieth century British banks and other financial institutions', paper presented at the XIV International Economic History Conference, Helsinki, 2006.

22 M. Ackrill and L. Hannah, Barclays: the Business of Banking 1690-1996 (Cambridge, 200I).

23 F. J. Ellis, 'New lamps for old: part I', The Spread Eagle, 6.8 (I93 I), pp. 404-7, 'New lamps for old: part II', The Spread Eagle, 6. 9 (I93 I), pp. 466-9, 'New lamps for old: part III'. 
to the vantage point from which he had gained his second point, Ellis drew experience from his employment in the Chief Foreign Branch, a discrete, semi-autonomous section of Barclays Bank, which had extensive links with foreign banks, and one where the new machinery had already been successfully introduced. Fourthly, it is significant that the editorial preface to this survey reveals that senior Barclays' staff, who would readily have admitted that the bank was a relative laggard in the adoption of this new technology, assumed that staff at the majority of their branches already had some acquaintance with the new technology. Fifthly, and finally, his article demonstrates an informed and profound awareness of the implications of bank mechanisation, defined broadly to encompass a full range of a clearing bank's operations. As Ellis wrote:

The modern bank organiser does not buy machines merely because they are a novelty, or just surround himself with machinery. On the contrary, he works to a very definite and logical plan. He studies the transactions and material the bank - in the department or branch he is investigating - is called upon to handle, having regard to volume, frequency of 'peak loads' and so forth. Thence he turns to the shape in which the results are desired. He must pay attention, also, to the various points to be covered in arriving at those results. All the while he keeps in mind the general lines of the bank's policy and the requirements and satisfaction of the clientele. These are the conditions under which he draws up his plan to provide the desired results as quickly, as economically and as efficiently as possible. Having made the outline of his plan, he next selects the machines and devices which, in his judgement, will best aid the staff in the consummation of the scheme. ${ }^{24}$

It is most telling that, as early as I93 I, a senior manager in the bank which itself accepted that it was the slowest in the 'Big Five' convoy en route to mechanisation was writing about this process, employing such telling phrases as: 'the modern bank organiser', 'general lines of the bank's policy', 'logical plan', 'consummation of the scheme', 'efficiently' and so on.

In the late I930s, after a brief pause when the depths of the international recession coincided with a period of consolidation, the 'Big Five' high street banks recommenced their drive to mechanised banking, with the minimum threshold of branch size being set at lower and lower limits. Interestingly, given the debate about the limited impact of managerial accounting upon strategic decision making, this assessment was informed by detailed information concerning standardised gauges of branch size and performance. These indicators included the number of staff, accounts, and transactions, financial resources and profitability. Even in smaller retail branches, where mechanical banking was viewed as uneconomic, at least one of the clearing banks aimed at the extension of mechanisation with the objective of achieving rationalisation and standardisation. However, the economic effects of World War II and its dire economic aftermath, both exacerbated by a stringent foreign exchange shortage, put a brake on further bank mechanisation and this halt to further diffusion lasted until the existing technology was approaching the end of its effective lifespan.

24 Ellis, 'New lamps for old: part I'. 
IV

Mechanisation of accounting functions indicated how clearing banks and building societies, like their counterparts in the USA, were anticipating an increased workload resulting from the greatly increased number of personal accounts which would follow from the projected increase in wage payments made by cheque. Without mechanisation this increased workload would require even larger numbers of employees which, taken with increasing unionisation amongst bank workers and generally rising wages, implied a significant rise in costs. It is worth noting that the initial adoption of new technology in banks had been closely associated with the recruitment of female bank clerks. Females were perceived as more proficient in the use of keyboards and awarded significantly lower rates of compensation. This transformation of the bank as a working environment during the interwar years was followed after I950 by building societies. There were other causes here, including relative rates of pay, changed social attitudes to women's work and the residual impact of recruitment of women in both World Wars, which ensured that gender was a factor that influenced both the adoption of machine banking in the late I920s and the post-I950 adoption of computers. ${ }^{25}$ But as had been the case with their counterparts in the USA, British banks were feeling the strain of a high turnover of female clerical workers, particularly in London and Birmingham. ${ }^{26}$ In such circumstances, Channon argues that banks 'turned gratefully to computers, which could be used to handle routine business and increase the strained capacity of many small [retail] branches'. ${ }^{27}$ Computerisation reduced costs and 'helped towards a slow but steady reduction in the number of [retail bank] branches' ${ }^{28}$ Significantly, at this time the building societies, still at a different stage of the mechanisation process, employed computers to continue to expand their networks of retail branches, which were now increasingly replacing agents as the primary point of contact with their customers. ${ }^{29}$

The 'Big Five' clearing banks had recognised the potential of 'mechanical banking' to overhaul management structures and introduce new systems of management control as early as the I920s. Their responses to these opportunities were often implemented as local initiatives designed to meet internal needs, though American practice was influential. In the I950s British banks and building societies were similarly aware of developments in the design of new technology and its application

25 Wardley, 'Women, mechanization and cost-savings'.

26 Alan E. Booth, 'Technical change in branch banking at the Midland Bank, I945-75', Accounting, Business and Financial History, I4. 3 (2004), pp. 277-300.

27 D. F. Channon, British Banking Strategy and the International Challenge (London, I977).

28 Ibid.

29 Bernardo Bátiz-Lazo, 'Depreciation of buildings in mutual financial services, circa I959' paper presented at the British Academy of Management, Oxford, 2005; Bernardo Bátiz-Lazo, 'Strategic alliances and competitive edge: insights from Spanish and UK banking histories', Business History, 46. I (2004), pp. 23-56; Bernardo Bátiz-Lazo and Mark Billings, 'In search of a winning strategy: a case study of strategic change at the Woolwich Equitable Building Society (I950-70)', in Fifth Accounting History International Conference (Banff, 2007). 
across the Atlantic. As with their earlier experiences with mechanisation, the implementation of computer technology resulted in the adoption of distinctive organisational solutions in the UK. ${ }^{30}$ International, inter-organisational and intraorganisational differences, however, tended to dissolve as the diffusion of technological change produced some convergence of practice. ${ }^{31}$

In the USA, during the I920s banks experienced a period of growth that continued in spite of the Great Depression although, unlike England, this growth was not reflected in the expansion of retail branch networks, which were prohibited by law, and US banks remained relatively small by British standards. An indicator of this growth of banking business in the USA was the increasing number of paperbased transactions. Yavitz estimated that approximately one and a half billion cheques were cleared in I939, and this volume increased to 6.5 billion in I950 and to 13 billion in $1960 .{ }^{32}$ Consequently, "the spectacular rise in cheque volume and activity, with no corresponding increase in the value of deposits, placed a severe strain on the [American] banking system'. ${ }^{33}$ By the early I950s this had become a critical problem and, as cheque clearing was expected to continue to grow, the banks recognised the need for a specialised mechanical aid: a cheque-reading machine that mechanised this important accounting function.

However, in the decade that followed the end of World War II, although computer manufacturers saw profitable business to be obtained from applications sold to the military, commercial aircraft manufacturers, research laboratories and industrial users of advanced mathematics and statistics, they were unwilling to invest in a system that would help in the proof reading and book-keeping of cheques. ${ }^{34}$ Consequently, banks led this field when the Bank of America approached the Stanford Research Institute to design and eventually build a prototype. This required the interconnection of tabulating machines, sorters, punched-card readers and hybrid computing technology; and combining transistors, vacuum tubes and operational amplifiers. This system, Electronic Recording Machine-Accounting (ERMA), required some \$IO $\mathrm{m}$ and three years of work and was launched in September I955.

30 Wardley, 'The commercial banking industry'.

31 Bernardo Bátiz-Lazo and Douglas Wood, 'Management of core capabilities in Mexican and European banks', International Journal of Service Industry Management (Special issue on Service Management in Latin America), Io. 5 (I999), pp. 430-48; B. Bátiz-Lazo and D. Wood, 'Strategy, competition and diversification in European and Mexican banking', International Journal of Bank Marketing, 2 I. (2003), pp. 2002-I6; Bernardo Bátiz-Lazo and Nurdilek Hacialioglu, 'Customer value creation in European financial services', International Journal of Bank Marketing (forthcoming); B. Bátiz-Lazo, Robert R. Locke and Kristine Mueller, 'Transferring Rhineland capitalism to the Polish-German border: perceptions of bank governance and practice in Zgorzelec-Görlitz', International Journal of Bank Marketing (forthcoming).

32 Boris Yavitz, Automation in Commercial Banking (New York, I967).

33 Ibid., p. I I.

34 James L. McKenney and Amy Weaver Fisher, 'Manufacturing the ERMA banking system: lessons from history', IEEE Annals of the History of Computing, I 5. 4 (1993), pp. 7-26; Yavitz, Automation. 
The development of ERMA primarily addressed the way in which the Bank of America recorded the history of individual transactions and performed the book-keeping of current account balances. The new system left procedures for organisational control or identifying the profitability of individual services unchanged. The efforts of the Bank of America and the Stanford Research Institute, however, did change the banking industry when other banks built their practices around innovations associated with ERMA. In particular, the Bank of America's magnetic character recognition patents became the standard when electromechanical clearing of cheques was adopted by the American Bankers Association (ABA) between 1954 and $1960 .{ }^{35}$ Later this would also be true for credit card standards.

The ABA standards, with minor adaptations, were also adopted in the UK. Although an early history of mechanisation at the clearing house has yet to emerge, links to developments in the USA and the importance of mechanical aids to this process are indisputable: the Electronics Sub-Committee of the Committee of London Clearing Banks was set up in I955. This was a major force in the process leading to automation, and was chaired and run by 'Barclays men', who were also delegated to oversee the talks at the ABA. Later Barclays Bank and Martins Bank pioneered the use of computers by opening dedicated centres for branch book-keeping. Although it took from I96I to I974 for Barclays to put all its retail bank branches 'on-line', without this development it would have been impossible for Barclays to introduce its network of automatic teller machines (ATM) in the mid I970s. ${ }^{36}$

Automation also took place within the Bank of England with the introduction of Power-Samas tabulators to assist in the payment of dividends in I96I. ${ }^{37}$ In February I965 initial steps were taken to establish what was to become the Audit Department's Computer Division. ${ }^{38}$ Together with the Organization and Methods Department, this group spearheaded the uncontroversial introduction of an ICL I309 (working in tandem with an IBM 360) to replace the tabulators in I967. By contrast, the migration of War bonds to magnetic tape storage gave rise to an internal debate (mirroring one amongst City auditors) as to what, in the face of the increasing computerisation of activities, could be regarded as acceptable from an audit point of view. ${ }^{39}$ The Bank of England's concerns about the audit of electronic media resulted in J. P. Jensen, General Auditor of the Federal Reserve Bank of New York, extending

35 Yavitz, Automation.

36 B. Bátiz-Lazo, 'Emergence and evolution of ATM networks in the UK', paper presented at the Business History Conference, Cleveland, OH, 2007.

37 Bank of England Archives [henceforth BoEA], Registrar's Department: Computer Services Files: Power Samas Installation (27 June I960 to 24 May 6I) (AC24/5).

38 BoEA, Audit Department Files [hence forth ADF]: The Audit Department's Approach to Computers (I2 July i967) (5Ai99/5).

39 BoEA, ADF: Magnetic Tape Registry (3 I March I967) (5Ai99/5). See also Institute of Chartered Accountants of England and Wales, An Audits Approach to Computers (London, I966). 
to E. de M. Rudolf, Auditor, and Tony Ockenden, 3rd Auditor, an invitation to a face-to-face meeting in America. In his original invitation Jensen noted that:

It occurred to us that your studies in the computer area of auditing work, an area which is relatively new to all of us, might be advanced ... [A visit], I think, can be more productive than communication by mail, particularly when the subject is novel and complex as the one we are considering, i.e., the potentialities of the computer for internal control and auditing purposes. ${ }^{40}$

Although computerised accounting was in its infancy at the Federal Reserve, Jensen indicated his expectation that computers would bring about important changes in processes, procedures and organisational capabilities. The four-day visit took place in September 1967 and besides electronic data processing, topics included the scope of the various audits, the recruitment and training of staff, operational audits, and statistical sampling techniques' ${ }^{41}$

The frank and open exchange between Jensen and de M. Rudolf mirrored a longestablished exchange of information between London and New York. ${ }^{42}$ British banks and the larger building societies were also watchful of developments in automation and the introduction of computer power in the USA. For instance, the development of electronic book-keeping methods that used computers in banking prompted the visit of A. M. MacGregor, manager of the Midland Bank's Machine Department (significantly renamed Operations and Methods in I96I), to the USA in I956. ${ }^{43}$ Senior managers of building societies also learned of developments in computer technology from directors who had visited the facilities of computer manufacturers and reported on developments in the mechanisation of accounting at savings and loans institutions in the USA. ${ }^{44}$

\section{$\mathrm{V}$}

According to Channon, in the late I950s and early I960s UK computer manufacturers had an incentive to enter the market for commercial applications because banks and other financial service organisations began to invest heavily in the computerisation of its processes and procedures. ${ }^{45}$ Indicative of this was the installation of an IBM I4OI in I959 by the Bank of Scotland. ${ }^{46}$ Another more general

40 BoEA, ADF: letter from J. P. Jensen to E. de M. Rudolf (28 April I967) (5Ai99/5).

41 BoEA, ADF: letter from J. P. Jensen to E. de M. Rudolf (io May ig67) (5Ai99/5).

42 Within three years of its creation in I9I 3 the Federal Reserve Bank of New York opened an account with the Bank of England; is not clear whether regular weekly correspondence started then, in I9I6, or in 1926 (BoEA, FRBNY Weekly Letters, C9).

43 Anonymous, 'The computer - and the story behind it', Midland Bank Staff Magazine, January (I963), pp. $432-3$.

44 R. Redden, A History of the Britannia Building Society (1856-1985), (London, I986); B. Ritchie, We're with the Woolwich: the Story of the Woolwich Building Society 1847-1997 (London, I998).

45 Channon, British Banking Strategy and the International Challenge.

46 R. Saville, Bank of Scotland: a History (1695-1995) (Edinburgh, I996). 
sign of the times was the final determination of the United Kingdom government to introduce decimal currency that had been regarded by some, albeit incorrectly from a technical standpoint, as an impediment to further mechanisation in the United Kingdom.

In 1960 the purchase by Lloyds Bank of a Burroughs B.Io I Sorter-Reader was seized upon by its manufacturer to demonstrate the benefits of automation to other clearing banks and to building societies. ${ }^{47}$ Burroughs organised demonstrations of this equipment where directors of other financial intermediaries were shown an American-produced film that also showed the posting of accounts on the B.25I Visible Record Computer coupled with the B.Ior Sorter-Reader and the P.700 Amount and Account Number Printer. ${ }^{48}$ These exhibitions indicate the sustained efforts made by American manufacturers to disseminate information about their technology in the UK.

Major local competitors to American-developed computer technology for commercial applications included Power-Samas and Lyons. In postwar Britain PowersSamas was the main supplier of accounting machinery to the clearing banks. ${ }^{49}$ Although Powers-Samas had expertise in the development of devices to handle punch-cards and could see the commercial potential of a cheque reader, it recognised that the development of this technology was beyond its own resources. In an attempt to remain a major force in the sector the chairman of Powers-Samas, Col. A. T. Maxwell, arranged a secret and historic meeting with British Tabulating Machine Company Limited (BTM) in 1956 that resulted in the establishment of a joint working party to determine a strategy for a joint venture in bank mechanisation. This initiative proved to be the first step towards a merger of the two companies as International Computers and Tabulators Limited (ICT) in I959. ${ }^{50}$ By I958 BTM had developed, in conjunction with an undisclosed American firm, a large-scale computer for use in banks and similar organisations. ${ }^{51}$ By contrast, Lyons' LEO II was sold to industry for general data processing, while Ferranti's Pegasus II found users amongst financial service organisations, including Martins Bank. ${ }^{52}$

47 Woolwich Equitable Building Society [henceforth WEBS], 'Brief Report on Automation' [henceford BRA], Barclays Group Archives, Manchester, 4 April I960, Ref. I44.

48 The B.Ior Sorter-Reader was a high-speed digital sorter, primarily intended to be used by banks for sorting cheques and credit slips into branch and account number before posting. It read magnetised figures and sorted documents at approximately I 500 a minute, into I 3 sections - Io for the main digital sort, 2 for special items, I for rejects.

49 Martin Campbell-Kelly, ICL - A Business \& Technical History (Oxford, I989).

50 Ibid.

51 R. S. Edwards and H. Townsend, Business Enterprise: Its Growth and Organisation (London, I958).

52 WEBS, BRA, 4 Apr. I960, Ref. I44. See also J. Hendry, 'The teashop computer manufacturer: J. Lyons, LEO and the potential and limits of high-tech diversification', Business History, 29. I (1987), pp. 73-IO2, which adds a cryptic reference, apparently to F. M. Fisher, J. W. McKie and R. B. Mancke, IBM and the US Data Processing Industry: an Economic History (New York, I983). 
British computer manufacturers fought hard to position their products, but the superiority of American technology became ever more apparent. At the Woolwich Equitable Building Society (Woolwich), for instance, the decision to invest $£_{200,000}$ in 1960 in computer equipment led to considerations of a tailor-made system, specifically the adaptation of STC's Stantec Zebra transistorised computer with paper tape reader and Creed 1000 printer. ${ }^{53}$ The Woolwich also considered machines produced by companies at the forefront of computer technology including NCR, ICT (Hollerith-Powers) and IBM.

Ferranti equipment was notable because, instead of using the magnetic characters that characterised Burroughs equipment, information was read into the computer on perforated or magnetised tape to be stored in 'memory drums'. Account statements and other information could then be produced very speedily, as and when required. Despite this apparent strength, Ferranti's directors foresaw insufficient demand to justify substantial investments in production facilities or persist with the development of mainframe computers. When faced with a liquidity problem Ferranti, a familyowned firm, decided to abandon commercial computers and focus its resources on defence sectors. As a result, Ferranti lost its lead in mainframe computers for general commercial use and mainframe computers were finally divested in $1963 .{ }^{54}$

Meanwhile, in I96 I Barclays demonstrated the viability of the new computer technology by successfully introducing an EMIDEC I IOO to process the accounts of its Pall Mall district which operated 40,000 accounts. This proved to be the first step in the process of diffusion of computerisation throughout Barclays. Shortly after, managers introduced what proved to be an over-ambitious scheme to mechanise all banking activities with a system built around a Burroughs 8500 . For British banks this was a rare example of a bold venture at the cutting edge of technological progress, and one which demonstrated the benefits of the alternative, and quickly vindicated, strategy of adopting promptly technology which was already tried and tested. Although the careers of the senior managers involved were not damaged by this adventure, a further demonstration of sound judgement on the bank's part concerning the nature of business strategy, the lesson provided by this experiment was not lost on Barclays' competitors. ${ }^{55}$

Further developments, in both the financial services offered and the information technology used to deliver these services, followed apace among all the major banks. A year later, the Westminster Bank, true to its tradition as an interwar trailblazer, became in I962 the first UK bank to provide its customers with cheques printed to include machine-readable information which facilitated automatic sorting.

53 The Chairman of the Woolwich was also Chairman of STC and, not surprisingly, pushed the former to link up with STC but, in the end, the Woolwich's Accountant and STC's engineers recommended against it.

54 John F. Wilson, 'International business strategies at Ferranti, I907-75: direction management and performance', Business History, 40. I (I998), pp. I00-2 I.

55 Ackrill and Hannah, Barclays. 
By adoption of this advanced, but not pioneering, information technology the Westminster Bank was able to centralise further accounting functions which had remained at retail branches. The pace of adoption, and the nature of the developments taking place in parallel in the banking industry, was demonstrated within twelve months when Coutts \& Co, a private bank owned by the National Provincial Bank, another of the 'Big Five' English high street banks, adopted a fully computerised accounting system which encompassed all of its branches. ${ }^{56}$ The adoption of a fully integrated system at Coutts also demonstrated well three other points: first, that bank size was not the only determinant of adoption of new technology, the private bank was but a fraction of the size of its parent; second, that the National Provincial, again continuing a tradition established in the I920s, was able to trial new technology in a constituent bank; and, third, as Coutts was a London-based bank that conducted most of its business in the capital, that even in I963 provision of a networked system was easier to achieve within a region than was the delivery of a comprehensive national service.

In summary, during the three decades that followed World War II, British banks began to plan for and implement the introduction of computers. This second stage of bank mechanisation can be characterised as an evolutionary story of assessment, innovation, and diffusion, followed by reappraisal and further innovation.

\section{I}

Building societies followed clearing banks and manufacturing firms in the sequential introduction of office equipment, punched card technology, tabulating machines and, most latterly, computers. However, amongst the building societies the diffusion of office technology was quite diverse, with leadership provided by the larger institutions. Table I offers in summary form a profile of selected building societies and indicates the timing and nature of their initial major investment in computing technology. Amongst the building societies the diffusion of computer technology took some twenty years, with the largest institutions the early adopters and the smaller ones the laggards. Interestingly, evidence has yet to emerge that would reveal the extent to which building societies sought to share costs through either jointly owned or independent computer bureaus (such as those offered by the Post Office and powered by ICL machines; and Westminster Bank's shared accounting service for societies at Centre-File Ltd). Manual, paper-based administrative systems (aided by visible record technology such as the Burroughs Sensitronic F4200 or NCR 500 Series) could have prevailed amongst some of the laggards until the late I970s or even the I980s, when personal computers were adopted.

An early pioneer in the sector, the Co-operative Permanent Building Society (CPBS) acquired its first tabulating machines from BTM in I944. These machines

56 www.royalbankscot.co.uk/Group_Information/Memory_Bank/Our_History/

Group_Constituent_Histories/coutts.htm date accessed I March 2003. 
Table I. Adoption of mainframe computers by selected building societies, 1963-1982

\begin{tabular}{|c|c|c|c|c|c|c|c|}
\hline & $\begin{array}{l}\text { Abbey } \\
\text { National }\end{array}$ & $\begin{array}{l}\text { Co-operative } \\
\text { Permanent }\end{array}$ & Halifax & $\begin{array}{l}\text { Leek and } \\
\text { Westbourne }\end{array}$ & $\begin{array}{l}\text { Bradford E } \\
\text { Bingley }\end{array}$ & Anglia & $\begin{array}{c}\text { West } \\
\text { Bromwich }\end{array}$ \\
\hline \multicolumn{8}{|l|}{ General information } \\
\hline Established & I 849 & I 884 & I 853 & I 856 & I 85 I & I 848 & I 849 \\
\hline Incorporated & I944 & I 884 & I 875 & I 879 & I964 & 1923 & I928 \\
\hline $\begin{array}{l}\text { Achieved national branch } \\
\text { coverage }\end{array}$ & I948 & I952 & I937 & I972 & I965 & $\mathrm{n} / \mathrm{a}$ & $\mathrm{n} / \mathrm{a}$ \\
\hline \multicolumn{8}{|l|}{$\begin{array}{l}\text { Adoption of mainframe } \\
\text { computer }\end{array}$} \\
\hline Year installed & I963 & I967 & I967 & I968 & I968 & I97I & I982 \\
\hline Make & Honeywell & IBM & IBM & ICL & IBM & ICL & ICL/Nixdorf \\
\hline Model & $4 \mathrm{OI}-\mathrm{A}$ & $360 / 30$ & $360 / 40$ & System 4-40 & $360 / 30$ & $\mathrm{n} / \mathrm{a}$ & $\mathrm{n} / \mathrm{a}$ \\
\hline Total membership & 844 , I IO & 826,426 & $\mathrm{I}, 654,832$ & 317,646 & 246, I6I & 398,28 I & $22 \mathrm{I}, 924$ \\
\hline Number of retail branches & $\mathrm{IO} 4$ & I 27 & I 46 & I06 & 72 & 54 & 88 \\
\hline Number of agencies & $\mathrm{n} / \mathrm{a}$ & $\mathrm{I}, 29 \mathrm{I}$ & $\mathrm{n} / \mathrm{a}$ & 300 & $\mathrm{n} / \mathrm{a}$ & $\mathrm{n} / \mathrm{a}$ & I7 \\
\hline Rank (assets) & 2 & 3 & I & 8 & IO & I I & 23 \\
\hline $\begin{array}{l}\text { Asset size at year-end of } \\
\text { adoption }\end{array}$ & £.559 m & $£ 524 \mathrm{~m}$ & $\AA_{\mathrm{I}, 296 \mathrm{~m}}$ & $f^{243} \mathrm{~m}$ & £i97 m & $\AA_{2} 299 \mathrm{~m}$ & $£ 336 \mathrm{~m}$ \\
\hline
\end{tabular}

Source: Company histories, Building Society Association Yearbook (1963-82) and authors. 
were introduced to enhance working conditions of senior staff at the Mortgage Department. In I946, individual account control was devolved to staff at retail branches and this was accompanied by the purchase of I 2 additional adding and listing machines to support the growing network of branches and agents. However, it was only after I95 I that the potential of these machines, as well as of punch-hole 'accounting' machines purchased in 1945, was fully exploited when the building societies experienced significant expansion as a result of policies introduced by the Conservative Government to encourage home ownership. ${ }^{57}$

The CPBS and other societies, including the Provincial and NALGO (National and Local Government Officers' Association), used a combination of the Hollerith 80-column card system and electronic equipment to generate monthly ledgers. Whereas Hollerith cards were processed by electrical contacts, Powers-Samas machines processed cards by 'feeling' punches with small rods. The electronic and punch card technology used by the latter was preferred at the Alliance Building Society, one of the largest ten societies (by assets). Mechanisation at the Alliance is a good example of how the introduction of calculating machines resulted in the substitution of sorters and sorter readers for manual clerical work to prepare monthly and daily ledgers.

In I957 the Alliance was described as 'an experienced user of punched cards to generate monthly ledgers for individual retail branches'. ${ }^{58}$ Forty-column cards (with separable mortgage accounting cards for cash, balances, monthly debits and annual insurance debits) were created from a combination of summary listings ('till sheets') and individual slips. Before processing, the cards were checked by a special team of clerical staff who confirmed that credits were mortgage repayments and debits had the correct account number and identifier. Instead of a 'check digit' the Alliance used the first three letters of the borrower's or depositor's surname. This was deemed of great assistance to ensure that the cash card was married to the correct balance card before posting. ${ }^{59}$ Confirmation was necessary because a full listing of account numbers was not always available for staff at retail branches. Following procedure, staff at the branch would add the address of the individual member to a credit or debit slip. At each one of the society's retail branches, credits to a member's (i.e. customer's) account had to be matched to a cheque, deposit slip at a clearing bank or deposit slip.

Cards were then passed at a rate of up to 6,000 per hour through each stage of the system, namely, conversion to punched card, tabulator, collator, calculator and posting transfer interpreter. Interest warrants would be printed on continuous stationery, which was imprinted first by the addressed system and subsequently by the

57 Bátiz-Lazo, 'Depreciation of buildings in mutual financial services, circa I959'.

58 WEBS, Electronic Accounting [henceforth EA]; Ref I The use of electronic and punched card accounting equipment by building societies, c.I957.

59 WEBS, Visit to the Alliance Building Society's Punch Card Accounting Installation [Visit to the Alliance]: Ref I: Practical points applicable to any punched card system, 5 April I957. 
Powers tabulator (which would also leave a trace through punched paper tape.) However, interest was not calculated by the tabulator. Interest for long-term deposits ('share interest') was calculated half yearly by the branches and checked at head office ('Chief Office'). Mortgage balances were tabulated and sent to an outside advisory agency where the annual interest was calculated and noted on the card for return to the society where the interest was punched.

When the addresses had been printed on the forms, these were called over with a tabulation of current balance cards. After 'call-over', the balance cards were arranged in the same order as the addressed warrants. The addressed warrants were then fed into the machine with the cards and, automatically, the account number and capital and interest amounts were printed. The warrants were then checked and initialled, the checker's duties being limited to verification that the account numbers in the address section and the financial section agreed. The Alliance had three mortgage payment dates: the first, second and third Tuesdays in the month and, consequently, three posting dates. All the cards for each posting date were fed through the tabulator for posting at one time and there was a monthly arrears debit for every account.

The Alliance ran term deposits ('investments') and mortgages through different equipment. Burroughs equipment was initially used and then Powers-Samas introduced for both systems. The Powers equipment 'was custom-built and [was] not formed of interchangeable units'. ${ }^{60}$ Changing from Burroughs to Powers-Samas equipment required from six months to a year and, with one exception, all the operators had to be retrained; their specific skills meant that former Burroughs operators were transferred to work elsewhere or left the society. Migration to the PowersSamas system resulted in the Alliance handling 'twice as many accounts as they had when they changed from Burroughs, with the same staff. Postings [were] more easily kept up to date and statistical information [was] more readily available'. ${ }^{61}$

The approach of the Alliance to centralise all individual account information at head office in Brighton contrasted sharply with that at the Halifax, traditionally the biggest of all the building societies in terms of assets (see Table I). The Halifax gave its retail branches full responsibility for the contents of account records and control of the administration of individual accounts. ${ }^{62}$ The Halifax used PowersSamas punched card equipment to summarise daily records of receipts and payments rather than to maintain individual accounts. After being sent daily to head office for processing, the records of each retail branch were analysed under various headings; this permitted the General Ledger to be written up daily to show an up-to-date financial position of the society. ${ }^{63}$

60 WEBS, Visit to the Alliance, Ref 2: The change-over from Burroughs and benefits.

61 WEBS, Visit to the Alliance, Ref 2: The change-over from Burroughs and benefits.

62 Anonymous, Computer Systems and Services (I979, Halifax).

63 WEBS, EA, Ref I: The use of electronic and punched card accounting equipment by building societies. 
Dissemination of office technology not only differed between the societies but also within the societies themselves. For instance, the clerical and book-keeping effort needed to deal with increased business volume within the most active retail branches of the CPBS was alleviated when, in I959, the society purchased three 'Sensimatic' Burroughs accounting machines (model F 203 - at a price of $\mathcal{E}$ I,595 each). These adding and ledger posting machines had part-manual and part-electronic features. They differed from previous models in that ledger sheets and statements could be posted simultaneously while the balance to be brought forward was stored in magnetic strips on the reverse side of the ledger sheet. ${ }^{64}$ The machines were located at offices in Nottingham, High Wycombe and Bradford (and later Belfast) while smaller book-keeping machines were relocated from those offices to retail branches in Swindon, Northampton and Middlesbrough where hand-operated technology persisted. ${ }^{65,66}$

Practices at the CPBS, the Alliance and the Halifax suggest that the influence of early mechanisation in the form of calculating machines and batch processing offered a cheap and efficient way to simplify book-keeping systems rather than developing methods by which to manage information. Simplifying book-keeping through mechanisation, however, also had some disadvantages and these became significant by the I970s. ${ }^{67}$ There were three major drawbacks. First, account decentralisation led to duplication of information; at the retail branches several listings of different records were required to update information on each account. Second, extended clearance; a branch could expect a four- to five-day 'turnaround', sometimes exacerbated by postal delays, between the occurrence of a transaction and its documentation in a centrally generated listing. Finally, congestion; the concentration of data preparation tasks in a single location, eventually called the Computer Centre, resulted in overcrowded staff and equipment.

The main challenge for the utilisation of electronic equipment by building societies 'was to devise [administrative] procedures for it and to provide suitable input and output equipment', ${ }^{68}$ This problem of peripheral input and output devices was similar to that encountered by J. R. M. Simmons at Lyons in the I950s where the

64 Anonymous, 'The computer - and the story behind it'.

65 Co-operative Permanent Building Society [henceforth CPBS], Board Minutes, Nationwide Society Archives, Nationwide Building Society, Wellingborough, 25 June I959 (Ref Accounting Machines).

66 Interestingly, a more advanced model of the same Burroughs accounting machine was still hailed as innovative in 1963. Ralph Stow, General Manager of the Cheltenham and Gloucester, claimed that two Burroughs Sensitronic F4200 machines sufficed to handle the daily postings of this medium size society (some 33,000 mortgage ledger accounts). This at a time when mechanical ledger posting was widely used by many other medium and small sized societies. See Ralph Stow, 'A venture into electronic accounting', Building Societies' Gazette, (I963), pp. 2I4-I 5.

67 Unless otherwise stated, data in this paragraph borrow freely from Anonymous, Computer systems and services, p. 2.

68 WEBS, EA, Ref 2: Reasons for the use of punched cards in conjunction with electronic means of accounting. 
need to link the clerical systems of the company to the computer necessitated the resolution of two difficulties: 'a hardware systems problem concerned with providing the appropriate input and output at the appropriate speed, and an engineering problem of converting from the decimal and sterling records of the office system to the binary form required by the computer and back again'. ${ }^{69}$ Despite its joint projects with various organisations, including the Post Office, STC, Ferranti and BTM, solutions to these problems were not easily found.

Although it was anticipated that mortgage financing would entail substantially higher administrative expenses than commercial loans, an additional impediment to the widespread adoption of office mechanisation in retail financial services was caused because the punched card technology of BTM and Powers-Samas offered limited storage possibilities. ${ }^{70}$ As punch cards could only accurately store information for single transactions, historical data were beyond their capacity.

Perhaps for that reason, directors of banks and building societies remained interested in the development of electromagnetic storage devices in the late I950s. These innovations were attractive as they promised more convenient input and output interfaces as well as the ability to arrange account information in a variety of ways. However, while Leo Computers Ltd. was recognised as the leading and most experienced manufacturer of the technology in 1957, building society managers hesitated when faced with the price tag of $£ 75,000$ for a Leo II (including ancillary reading and printing equipment). Automation offered improved levels of productivity but the adoption of data-processing equipment was price sensitive, as these were expensive acquisitions. Moreover, managers were aware that migration to a new administrative system could be lengthy and expensive. Unsurprisingly, directors of building societies wanted reassurance about the effectiveness of any new device:

I think it may be agreed that we would not wish to keep our records by [electronic/electro magnetic means] until these [systems] have been in practical use on a wide scale for many years. $^{71}$

However, directors of building societies could see a number of potential applications for electronic equipment, including general-purpose computing technology. This can be illustrated by a specific example (summarised in Table 2).

As Table 2 shows, monthly mortgage repayments were the largest item of accounting work for the Woolwich. Most of these payments were received through deposits at clearing banks that provided building societies with a 'posting medium which [was] sorted, listed and used for posting to the ledger account' ${ }^{72}$ Conveniently for both

69 Hendry, 'J. Lyons'.

70 Yavitz, Automation.

71 WEBS, EA, Ref 2: Reasons for the use of punched cards in conjunction with electronic means of accounting.

72 WEBS, Data Relevant to Utilisation of Electronic Equipment [henceforth DRUEE], Ref 3: Sources of Entry, 28 Jan. I960. 
Table 2. Data susceptible to application of electronic equipment (1960)

\begin{tabular}{lr}
\hline Investment accounts: shares and deposits \\
\hline Number of accounts (Actual) \\
\hline Share accounts & I 30,000 \\
Savings shares & 6,000 \\
Deposits & 30,000
\end{tabular}

Number of postings (Monthly average)

Receipts Payments

Share accounts $\quad 7,500 \quad 3,500$

Savings shares $\quad 6,000-$

Deposits $\quad 3,000 \quad 2,500$

Basis for interest calculation

- Share accounts - day-to-day interest of transactions.

- Savings shares - interest from the end of the month of deposit up to the beginning of the month of withdrawal. Monthly credit of interest to be received on every account.

- Deposits - interest from the end of the month of deposit up to the beginning of the month of withdrawal.

Preparation of interest warrants (Semiannual interest paid or credited on 30 June and 3 I December, based on transactions up to the previous month)

Num of half-yearly transactions

Interest sent by warrant $\quad 58,000$

Interest sent to banks $\quad 39,000$

Compounded

(i.e. added to capital) 28,000

Credited to deposit accounts 3,000

Notification to banks

One alphabetical run, according to name of 'investor', sorted into banks, listed and sent to bank with covering cheque.
Mortgages

Number of accounts: I IO accounts (requiring I 8 alphabetical runs on a regional basis)

Posting media (Sources of original transactions) Average of monthly mortgage repayments

Counters of retail branches I 8,000

By post and through agents $\mathrm{I} 5,000$

From banks 76,000

Information required on ledger

(Arrears and correspondence)

I. Debiting of advances.

2. Monthly posting of cash credits an all accounts.

3. Monthly notification to Arrears

Department on accounts which were two months in overdue (average 4,500 in Dec I959).

Application of variable interest rate charges Mortgage deeds contained conditions for changes in rates. The majority of mortgages provided for a regular monthly repayment but there were some 6,500 'Endowment Plan' mortgages (i.e. fixed interest and endowment period payable at irregular intervals).

Furnishing statements to borrowers

- Interest is based on the balance at the beginning of the year. The majority of the accounts carry interest at one rate.

- Annual statement of capital balance (total debited during the year and notice of balance due/remaining). 
Table 2. (Continued)

Investment accounts: shares and deposits ${ }^{\mathrm{a}}$

Mortgages

Furnishing data to Inland Revenue

- No income tax calculations were involved in the payment of interest. Under a special arrangement the society paid tax on behalf of long term depositors (i.e. "share investors").

- Details of a 30 per cent sample of individual account holders with balances of $\mathcal{E}_{\mathrm{I}} \mathrm{,o00}$ or more and three per cent of all other accounts had to be sent in intervals of three to four years. Details included name, address, total investment balance and total interest credited per year.

Channel (work flow)

Furnishing data to Inland Revenue

Notification of estimated interest for the coming year and actual interest debited for the previous year.

Insurance (Annual debit of fire insurance premiums)

Lady Day $\quad 55,000$

Midsummer $\quad$ I 7,500

Christmas 3,000

Channel

Holiday debits

Source: Woolwich Equitable Building Society, Brief Report on Automation, c. I964.

${ }^{a}$ We have used demand deposits, savings accounts and term investments for deposits, savings shares and share investment accounts respectively.

bank and society, transactions were distributed amongst banks' retail branches so that sorting and listing was also spread between several building society retail branches. Detailed information for the Woolwich shows that, in spite of having outsourced a number of paper-based transactions to clearing banks, the society's retail branches received on average around 2,500 paper-based transactions related to mortgage repayments; these comprised transactions at the counter of the society branch, postal deposits, agent payments and clearing-bank deposits. At this time, the Woolwich had 40 branches and 750 agents (of which only Ioo remitted some form of business on a daily basis), while 'larger branches might receive up to 8,000 mortgage [related transactions] per month'. ${ }^{73}$

73 WEBS, DRUEE, Ref 3: Sources of Entry. 
Banks automated before building societies despite the societies' complex organisational systems that accounted for deposits, term investments and mortgage payments; these were administratively more cumbersome and demanding than the simpler requirements of cheque clearance. In part, building societies seem to have lagged behind banks because they had a more 'relaxed' time frame in which to complete their processes. Indeed, where clearing banks in the UK had three to four days to credit or debit an account, building societies worked on monthly and semi-annual cycles.

As had been the case of both American retail finance and their British banking counterparts, the decision of a building society to automate, via the use of a computer, was based on perceived cost savings and a technological frame of reference that viewed the computer as a high-output paper-processing machine. ${ }^{74}$ According to Yavitz, the most important factor in evaluating the savings potential of a proposed computer installation in banking was the anticipated payback period; that is, the number of years of cumulative cost savings required to pay back the initial implementation cost. ${ }^{75}$ Payback was used as an indication of the effectiveness of the investment in new technology and Yavitz estimated payback periods in American banks during the mid I960s ranging from one and a half to eight years, with a three-year average and a three-and-a-half-year median. In 1963 directors of the Leeds Permanent estimated that " $[\mathrm{a}]$ large building society could install a computer system for $£ 20,000$ to $£ 30,000$ per annum at the most, writing it off over seven years... ${ }^{76}$ At the CPBS, it was estimated that capital costs and revenue expenditure would be compensated by savings emerging from automation over $\mathrm{I} 2$ years but only if the society doubled its size over that period and reached f, I,OOO $\mathrm{m}$ in total assets by I976. ${ }^{77}$

On balance, however, the nature and extent to which computer technology enhanced the workings of retail financial institutions were below expectations. Initially, there were promises that, through the adoption of computers, building societies could exploit, on a regular basis, previously inaccessible information such as summary figures and balances for mortgages and term deposits per retail branch. ${ }^{78}$ But evidence suggests that the introduction of the first computers failed to enhance information flows as, for example, profit and loss accounts of individual retail branches at the CPBS were only made available to senior management from I972. Computer developments at the CPBS appear representative of those at other building societies.

74 Yavitz, Automation.

75 Ibid.

76 A. Schofield, 'The electronic revolution', The Building Societies' Gazette (1963), pp. 50-I.

77 CPBS, Special Policy Board Meeting: Electronic Data Processing, Ref. 296.e Economics of E.D.P., I6 April ig64.

78 WEBS, The Effect of a Computer, Ref. Chief Office, I 3 March I964. 
Clearly, the most significant result of introducing programmable computing power was the substitution of high-speed equipment for manual clerical work and slowerspeed calculating machines. At the time, Mr A. Schofield, a director of the Leeds Permanent, opined that

It is, perhaps, no exaggeration to suggest that the installation of a computer system, satisfactorily working, and with its potential fully exploited, is likely to make redundant fully half of the staff, male and female, previously engaged in routine clerical work... This might well mean, in the long term, the recruitment into the chief office of university graduates (of which there may eventually be a plethora).... [while continuing to attract] the 'O' level male school-leaver [for the appointment of branch managers and staff]. ${ }^{79}$

Schofield's comment is remarkable for a number of reasons. On the one hand, he forecasts a fundamental shift in the mix of staff (to include the previously unheard of practice of attracting university graduates) but, on the other hand, he can not see an end to the long-established practice of internal promotion (i.e. internal labour markets). It is also striking that this diagnosis mirrors very closely that enunciated half a century before by senior bankers contemplating mechanisation in the late i920s.

Schofield's comment also acknowledges that a major force for the computerisation of certain routine jobs was the potential to lower headcount (by lower recruitment rather than redundancies) and increase financial returns. ${ }^{80}$ This is further illustrated through the pioneering efforts of the Abbey National. In I963 the Abbey used a Honeywell 400 to help eliminate handwritten passbooks, which were replaced by computer-processed pre-prepared record slips. Having paperbased slips directly routed to Lombard Street saved a considerable amount of work at the retail branches. ${ }^{81}$ It also had the advantage, for the society, of increasing the volume of funds cleared into an interest-bearing account; cleared funds could be invested two days earlier than had been the case prior to the adoption of computer technology. Building societies were thus alerted early on that significant positive effects on performance could accrue when investments in computer technology were matched with changes in complementary activities (such as organisational design, the creation of new jobs, recruitment practices or the access to financial markets). ${ }^{82}$

79 Schofield, 'The electronic revolution'.

80 J. R. S. Revell, Banking and Electronic Fund Transfers (Paris, I983), pp. 67, documents estimates of human tellers displaced by automated teller machines circa I980.

81 The Woolwich estimated that in November/December of I959, I/3 of borrowers used bank orders and I/ 6 credit transfers to pay their subscriptions. As a result half the number of payments accrued to bank-based transactions. The other half comprised transactions at retail counters or by post (I/3) and through agents (I/6). WEBS, The Effect of a Computer, Ref. Borrowers, I 3 March I964.

82 John Roberts, The Modern Firm (Oxford, 2004).. On investments in computers and complementary assets see Erik Brynjolfsson and Lorin M. Hitt, 'Beyond computation: information technology, organizational transformation and business performance', Journal of Economic Perspectives, I4. 4 (2000), pp. 23-48. 
The gains from the introduction of computers at head office included:

- The elimination of strain and extra work caused by peak loads associated with borrowers' annual statements, investor's warrants and statements, clearing returned interest warrants and changing interest rates.

- The possibility of exchanging magnetic tapes with clearing banks, which included details of mortgage credits that could be fed directly to the building society's computer.

- Much quicker turn around of mail, particularly with reference to the computer calculating redemption quotations and investment valuations for withdrawal.

- More flexible administrative systems. In particular with regards to arrears and the control of information at head office:

It was acknowledged that the reasons put forward for adopting E.D.P. [Electronic Data Processing] were similar to those which could be stated in considering the case for centralisation of accounts. The important aspect to be borne in mind, however, was that centralisation, other than on a computer system, would be impractical at this stage of the Society's development.

It is perhaps inevitable that there would be some loss of personal service to members but Management expressed the view that this was not likely to have any material effect on the development of the Society. ${ }^{83}$

Greater efficiency associated with automation suggested that managers and directors of building societies faced an apparent paradox. On the one hand, greater efficiency through automation would result in greater centralisation. On the other hand, enhanced service offerings to customers associated with devolution of discretion to customer-facing-staff at retail branches implied greater decentralisation. In part, this was resolved as improved supervision and enhanced control over branches allowed increased, but more closely supervised, delegation of responsibility to local staff. Senior managers opted for enhanced automation, in the form of newly introduced electronic and programmable computers, and improved communications, such as automatic internal switchboards. Automation resulted in the establishment of central accounting units and the centralisation of customer account control so that regional and retail branch managers might eventually lose autonomy to centralised senior managers. For instance, the central accounting unit of the CPBS was established at Chesterfield House in the summer of I966, and within a few months the first batch of the society's retail branches was using computer-style accounting numbers for all new business. Shortly afterwards this practice was extended to all of the 124 retail branches. ${ }^{84}$

83 CPBS, Special Policy Board Meeting: Electronic Data Processing, Ref. 296.b Centralisation of Accounts - Service to Members, i6 April i964.

84 M. Cassell, Inside Nationwide (London, I984). 


\section{VII}

Banks and building societies kept abreast of technological developments by dedicating internal resources. For instance, as late as I964, the board of the CPBS was introduced to the workings of IBM's System 360 equipment. ${ }^{85}$ This prompted the General Manager, J. H. Simpson, to appoint a Computer Manager and a Senior Programming Assistant. ${ }^{86}$ The new manager would head the newly created Computer Department (which replaced the Operations and Methods Department) and:

had to be experienced in the Building Society work and, in particular, to have a thorough knowledge of the Society's methods and administration procedures. He would also be required to attend courses in computer programming and other operations in order to carry the project through to installation. ${ }^{87}$

However, by the late I960s it was becoming increasingly evident that developments in the field of computer technology were exceeding the ability of in-house expertise in financial service organisations. Different equipment configurations presented a variety of advantages and disadvantages, turning the evaluation of equipment proposals into a complex technical task. For this reason top management in American and British financial institutions increasingly relied upon outside consultants to select the equipment for them:

The use of an outsider also tends to neutralise some of the biases of employees familiar with a particular manufacturer's equipment or of other financial or service ties with a particular manufacturer. Nevertheless, equipment selection is still, to some extent subjective. ${ }^{88}$

In the UK, the Bank of Scotland commissioned an investigation to work out profit objectives for the next five years for individual retail branches, design a mathematical model to simulate decision making and review internal accounting practices. The exploratory team was to comprise of internal staff from the Profit Planning Committee and the Management Accounting department as well as external advisors from PA Management Consultants. ${ }^{89}$ This consultancy project generated several reports including a feasibility study into rationalisation of branch locations and a

85 CPBS, Special Policy Board Meeting: Electronic Data Processing, i6 April i964.

86 Fenton F. Robb, 'Information technology and the accounting profession', in T. A. Lee, A. Bishop and R. H. Parker (eds.), Accounting History from the Renaissance to the Present (New York and London, I996) noted that mechanisation made it increasingly necessary to program work in an office as if for a production line. 'Due to the skills and knowledge required, there were not many people who could do more than a few of these jobs' (p. 204). However, contrary to evidence presented in this section, he claimed that 'most accountants and auditors preferred not to get involved in what was patently electro-mechanical engineering. These professionals tended to treat the whole computing function, from data preparation to printing, as just a huge black box' (p. 2 I I).

87 CPBS, Minutes of the Board, Ref: Computer Manager, 7 May I964.

88 Yavitz, Automation, p. 33.

89 Saville, Bank of Scotland: a History (1695-1995), pp. 689-92. 
summary of high level findings. ${ }^{90}$ Unfortunately, however, the only references to computerisation or databanks in these reports were strictly confined to the methodology and technology to be employed by the consultants themselves in delivering the study, and did not offer comments or recommendations for the use of computers by the Bank of Scotland. It appears that even external consultants were reluctant to suggest the use of technology to bring about significant changes in banks' internal procedures.

As for the building societies, the Woolwich's first computer was an IBM 360/30 mainframe. This was installed in a purpose-built unit at Bexleyheath in June I968 but only after a team of management consultants from Peat Marwick Mitchell had spent several months studying the Woolwich's accounting systems. The study was commissioned in 1965 and does not appear to have survived in full. ${ }^{91}$ But the intent of directors was that it should proceed 'with a view to recommending general improvements in the [accounting systems], including the possibility of the introduction of new forms of mechanisation based on electronic principles.' 92

In I967, top managers of The Heart of England Building Society also commissioned 'a national firm of Chartered Accountants' to review their accounting system. These discussions continued throughout I968 and led to an in-depth evaluation of accounting methods as well as the purchase of one Burroughs E2 I 54 machine and auto-reader. ${ }^{93}$

Meanwhile, the Leek and Westbourne appointed the auditing and accounting firm Price Waterhouse in 1968 as computer consultants. ${ }^{94}$ Their task was to carry out a feasibility study to find the best computer for the society's business and the best system of operation. 'Price Waterhouse had considerable experience in this kind of work, and particularly in competitive price ordering. ${ }^{95}$ As a result of this exercise, the Board decided to purchase a System 4-40 computer from ICL. At this time, the Leek and Westbourne Society boasted I06 retail branches and 300 agencies throughout the UK, with strong concentration in the north-west of England, London and the home counties. However, by then, 'modern communications and growing computerisation were anyway making geographical position irrelevant'. ${ }^{96}$ Twenty years later, the same conclusion could be drawn about the distinction

90 Although the nature of their contents is known, these reports remain closed to the external user because they contained confidential financial data and commercially sensitive observations. This paragraph is also informed by private correspondence with H. Redmon-Cooper, Archivist HBOS Group (27 Jan. 2003).

91 See comment on surviving elements of this report in Bátiz-Lazo and Billings, 'In search of a winning strategy'.

92 Ritchie, the Woolwich. 9I and WEBS, Minutes of the Meeting of the Finance Committee, Ref. Item 3, I7 June I965

93 P. W. Martin, History of the Heart of England Building Society (Warwick, I98 I), p. I67.

94 Redden, Britannia, p. 86.

95 Ibid., p. 86.

96 Ibid., p. 96. 
between banks and building societies when what had been for over a century parallel financial systems finally converged. Automation and the management of mechanised banking had played a major role in all aspects of this process.

\section{VIII}

For more than a century English banks and building societies have experienced a consistent process of change which has altered their nature, size and structure - they have also been the location of significant technological change. This process embraced both new machines and improved organisational methods. There is evidence that, when applying new technologies in banking practices, senior managers of clearing banks and building societies consistently engaged in a systematic process of assessment of the potential for additional profit or reduced cost. There are obvious signs that economic considerations determined both the decision to adopt or reject new technology and, when adoption was chosen, the selection of the preferred technology. Although managerial style in the financial sectors was often regarded by the public as somewhat cautious, if not 'conservative', the financial companies reviewed here tended to quietly play the role of pioneers in the application of new information technology. However, their public positions were strongly influenced by the perceived need to maintain the intermediaries' reputation and an image of 'stability'.

Lyons apart, with its own agenda in the development of information technology for the reformation of its business practices, it was the financial intermediaries that were the most significant customers for computer manufacturers who entered the business application market. At the same time, senior managers of clearing banks and building societies learnt early on that there was little competitive advantage in adopting the latest technology as opposed to adopting the most effective technology. And here the technical barriers should not be forgotten: for instance, the more rapid computerisation of retail financial services was hindered by the limited storage capabilities of the technology available at the time, rather than by additional costs.

Hence, UK clearing banks and building societies had very specific problems and adopted particular responses given the technology available at the time. In the realm of office machinery and mechanical accounting, these solutions favoured increased efficiency rather than effectiveness. Internal control procedures and business practices remained largely unchanged during a period of rapid technological change. It is only at the end of the period of our study, coinciding with yet another wave of automation, associated with new and more powerful computer technology after I968, and influenced by decimalisation in the UK in I97I, that the significant changes appeared in management information systems within retail intermediaries.

Authors' addresses:

School of Management

University of Leicester

Ken Edwards Building 
University Road

Leicester LE1 7RH

$U K$

b.batiz-lazo@leicester.ac.uk

School of History

University of the West of England

St Matthias Campus

Oldbury Court Road,

Bristol BS16 2JP

UK

peter.wardley@uwe.ac.uk 